\title{
Chemical composition, vitamins, and minerals of family farming biribiri (Averrhoa bilimbi L.) in the Middle Doce River region, Minas Gerais, Brazil
}

\author{
Jéssica Nunes Ferreira ${ }^{1}$ (D) Helena Maria Pinheiro-Sant'Ana ${ }^{2}$ (D) Ceres Mattos Della Lucia $^{2}$ (D) \\ Reinaldo Duque Brasil Landulfo Teixeira ${ }^{3}$ (i) Leandro de Morais Cardoso $^{1^{*}}$ (D)
}

${ }^{1}$ Departamento de Nutrição, Universidade Federal de Juiz de Fora (UFJF), 35020-470, Governador Valadares, MG, Brasil. E-mail: leandro.cardoso@ufjf.br. "Corresponding author.

${ }^{2}$ Departamento de Nutrição e Saúde, Universidade Federal de Viçosa (UFV), Viçosa, MG, Brasil.

${ }^{3}$ Departamento de Ciências Básicas da Vida, Universidade Federal de Juiz de Fora (UFJF), Governador Valadares, MG, Brasil.

ABSTRACT: This study evaluated physical characteristics, chemical composition, content of vitamin C, vitamin E, carotenoids, and minerals in biribiri fruits (Averrhoa bilimbi) from the Middle Doce River region (Minas Gerais, Brazil). Titratable acidity was determined by volumetric neutralization, $\mathrm{pH}$ by direct potentiometry, soluble solids by refractometry, humidity by gravimetry, ash by calcination in muffle, proteins by the micro-Kjeldahl method, dietary fiber by non-enzymatic gravimetric method and lipids using a Soxhlet extractor. Carotenoids and vitamin $C$ were analyzed by high-performance liquid chromatography (HPLC) and vitamin E by HPLC with fluorescence detector. Fourteen minerals were analyzed by inductively coupled plasma atomic emission spectrometry. Biribiri showed high yield of edible portion (100\%), low lipid, protein and carbohydrate content, and; consequently, low total energy value $\left(25.36 \mathrm{kcal} 100 \mathrm{~g}^{-1}\right)$. The fruit also showed low dietary fiber

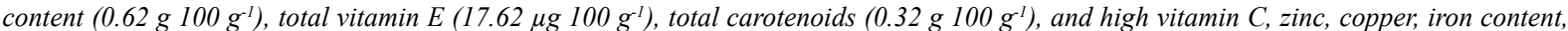
manganese, molybdenum and chrome content. Regarding the heavy metals, the fruit showed no cadmium, and traces of aluminum and nickel. In conclusion, biribiri presented low energy value and expressive contents of dietary fibers, vitamin $C$, iron, manganese, molybdenum, chromium, zinc, and copper.

Key words: nutritional value, unconventional food plant, bioactive compounds.

Composição química, vitaminas e minerais do biribiri (Averrhoa bilimbi L.) da agricultura familiar da região do Médio Rio Doce, Minas Gerais, Brasil

RESUMO: Este estudo teve como objetivo avaliar as características fisicas, a composição química, teor de vitamina C, vitamina E, carotenoides e minerais em frutos de biribiri (Averrhoa bilimbi) do território do Médio Rio Doce (Minas Gerais, Brasil). A acidez titulável foi determinada por neutralização volumétrica, o pH por potenciometria direta, os sólidos solúveis por refratometria, a umidade por gravimetria, as cinzas por calcinação em mufla, as proteinas pelo método micro-Kjeldahl, as fibras alimentares pelo método gravimétrico não enzimático e os lipidios usando um extrator Soxhlet. Os carotenoides e a vitamina C foram analisados por cromatografia líquida de alta eficiência (CLAE). A vitamina $E$ foi analisada por CLAE com detector de fluorescência e quatorze minerais foram analisados por espectrometria de emissão atômica com plasma indutivamente acoplado. O biribiri apresentou alto rendimento de porção comestivel (100\%), baixos teores de lipídios, proteinas e carboidratos e, consequentemente, baixo valor total de energia $\left(25,36 \mathrm{kcal} 100 \mathrm{~g}^{-1}\right)$. Os frutos também apresentaram baixos teores

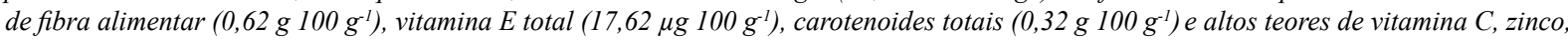
cobre, ferro, manganês, molibdênio e conteúdo cromado. Em relação aos metais pesados, os frutos não apresentaram cádmio e tiveram vestígios de alumínio e níquel. Em conclusão, o biribiri apresentou baixo valor energético e conteúdos expressivos de fibras alimentares, vitamina C, ferro, manganês, molibdênio, cromo, zinco e cobre.

Palavras-chave: valor nutricional, planta não convencional de alimentos, compostos bioativos.

\section{INTRODUCTION}

Averrhoa bilimbi L. is a fruit tree belonging to the oxalidaceae family, which also includes Averrhoa carambola L., popularly known as carambola (ALHASSAN \& AHMED, 2016). Although, of uncertain origin, Averrhoa bilimbi is naturally distributed and cultivated in tropical and subtropical countries (ALHASSAN \& AHMED, 2016). In Brazil, Averrhoa bilimbi is an endemic species popularly known as biribiri, bilimbi, Japanese lemon, cayenne lemon and yellow carambola, which occurs spontaneously in different Brazilian states (LIMA et al., 2001). In the Middle Doce River region, Minas Gerais, biribiri is reported in agroforestry-and family farming, which have as main role the diversified 
production of food for family self-consumption using ecologically sustainable management practices (FLORENTINO et al., 2007).

Although, biribiri has high economic and medicinal importance, the exploitation of this fruit tree, especially its fruits, is still incipient (SOUMYA \& NAIR, 2016). Due to the limited number of commercial crops, the distribution and marketing of biribiri fruits are very restricted. The green fruits of biribiri are used in the production of seasonings, vinegars, preserves and juices. Also, the ripe ones are consumed in natura or processed for the preparation of jams, and juices (ALHASSAN \& AHMED, 2016; ISTIQAMAH et al., 2019).

Research on the nutritional and phytochemical profile of unconventional food plants, such as biribiri, is increasingly important in the context of food security, sovereignty and conservation of agrobiodiversity in family agriculture, allowing access to a variety of species uncommon in the conventional market such as unconventional food plants. Information on the chemical composition of biribiri fruits native of Brazil is scarce in the scientific literature. This information is restricted to the physicochemical and physical composition $(\mathrm{pH}$, total soluble solids, total titratable acidity, weight, length, width and number of seeds), and the profile of polyphenols and antioxidants of the fruits (ARAÚJO et al., 2009).

Studies conducted with fruits originating in Asian or African countries have shown that biribiri is a good source of vitamin C (ARIHARAN et al., 2012) and has forms of vitamins such as nicotinic acid, pantothenic acid and tocopherols (MUHAMAD et al., 2015; ZAINUDIN et al., 2014). Asian and African fruits also presented minerals (sodium, potassium, calcium, magnesium, iron, manganese, zinc, selenium and chromium), heavy metals (lead and cadmium) (BHASKAR \& SHANTARAM, 2013; DANGAT et al., 2014; SOUMYA \& NAIR, 2016) and a diversity of phenolic compounds (cyanidine-3-O-glucoside, myricetin, luteolin, quercetin, apigenin and tannins) (MIEAN \& MOHAMED, 2001; RAMSAY \& MUELLER-HARVEY, 2016; YAN et al., 2013).

In view of the lack of information on carotenoids, vitamin $\mathrm{E}$ and minerals present in biribiri from Brazil, the high variability in the physical and chemical characteristics of grown fruits without anthropic interference and the variation of these characteristics due to genetic and edaphoclimatic factors of the cultivation sites (LIMA et al., 2001). This study determined the physical and chemical characteristics (macronutrients, vitamin $\mathrm{C}$, vitamin $\mathrm{E}$ and carotenoids and minerals) of biribiri fruits from family farming in the Middle Doce River region, Minas Gerais, Brazil. This research was proposed from the initial contact with biribiri and local agrobiodiversity through experiences of rural extension with family farming and local peasant organizations.

\section{MATERIALS AND METHODS}

\section{Characterization of the regional socio- environmental context of the fruit harvest}

The fruits were collected in November 2018 in a family farm called "Sítio Paraíso", located in the district of Chonim de Cima, in the municipality of Governador Valadares, MG. The property is located $36 \mathrm{~km}$ from the city hall, $21 \mathrm{~km}$ from Marilac and is 285 meters above sea level.

The region where Sítio Paraíso is located has a hot semi-humid tropical climate, with an average annual temperature of $24.2^{\circ} \mathrm{C}$ and an average annual precipitation of $1109 \mathrm{~mm}$. In addition, it has undulating relief, with areas of native vegetation, and cultivation of conventional and exotic fruits, vegetables, and legumes. Its soil is sandy in character due to environmental impacts in its surroundings; however, in the property these impacts are controlled due to its production based on agroecology and sustainable management of soil and crops, as well as recovery of springs and degraded areas.

The biribiri fruits were donated by family farmers through the Centro Agroecológico Tamanduá (CAT), which for 30 years has been providing technical advice and promoting rural extension to rural communities and agrarian reform settlements in the Middle Doce River region. Through the Network of Agroecological Prosumers Rede Tamanduá de Prosumidores Agroecológicos project, CAT has as main objective to bring the countryside and the city closer, promoting the direct commercialization of agroecological products in addition to transfer of knowledge and social technologies through participatory methodologies, contributing to the dialogue between the countryside and the university though, for example, the donation of agro-biodiversity products for extension and research activities carried out in educational institutions.

\section{Obtaining, sampling and sample preparation}

Biribiri fruits were harvested in three replications during the harvest (December 2018) on a family farm and; subsequently, transported to the laboratory in polystyrene boxes within a maximum of 24 hours after harvest. 
In the laboratory, the morphologically perfect and "semi-ripe" fruits, characterized by their slightly yellow color, were selected, washed under running water, and dried on paper towels. Then, the fruits were manually quartered with the aid of a stainless-steel knife and two opposite quartiles were selected in each fruit. The selected quartiles were homogenized in a food processor (Faet Multipratic, MC5, Brazil), packed in polyethylene bags and stored in a freezer $\left(-18^{\circ} \mathrm{C} \pm 1^{\circ} \mathrm{C}\right)$ for further analysis.

\section{Physical characterization of fruits}

The individual measures of the height and diameter of 30 fruits (10 repeating units) were obtained with the aid of a digital caliper. The fruit mass was obtained by direct individual weighing on a semi-analytical balance (Gehaka, BG 2000, Brazil).

\section{Chemical and physicochemical analysis of fresh pulp}

The chemical analyses were performed in three repetitions. Values of titratable acidity, soluble solids and pH(LUTZ, 2008); moisture, ash, protein, lipids and total dietary fiber (AOAC, 2016) were determined. The carbohydrates were calculated by subtraction using the formula $: 100$ - \% moisture - \% lipids - \% protein $\%$ of total dietary fiber $-\%$ ash. The total energy value was estimated considering the conversion factors of 4 Kcal.g ${ }^{-1}$ of protein or carbohydrate and $9 \mathrm{Kcal}^{-1} \mathrm{~g}^{-1}$ of lipid (MAHAN et al., 2005).

\section{Determination of carotenoids and vitamins}

During the extraction and analysis of carotenoids and vitamins from the biribiri pulp, the samples and extracts were protected from light, solar and artificial, using amber glass, aluminum sheets and blackout curtains. The extracts were protected from oxygen using flasks with lids, with a nitrogen environment.

The carotenoids ( $\alpha$-carotene, $\beta$-carotene, $\beta$-cryptoxanthin and lycopene) of the fresh pulp were extracted in acetone and transferred to petroleum ether (RODRIGUEZ-AMAYA et al., 1976), modified using a RP-18 Phenomenex Gemini chromatographic column, 250 x $4.6 \mathrm{~mm}$, $5 \mu \mathrm{m}$, fitted with Phenomenex ODS (C18) guard column, 4 × $3 \mathrm{~mm}$. Carotenoids were analyzed using a high-performance liquid chromatography system (HPLC) (Shimadzu, SCL 10AT VP, Japan) comprising a high-pressure pump (Shimadzu, LC10AT VP, Japan), an autosampler with a loop of $50 \mu \mathrm{L}$ (Shimadzu, SIL-10AF, Japan) and a diodearray detector (DAD) (Shimadzu, SPD-M10A, Japan). The chromatographic conditions used were developed by PINHEIRO-SANT'ANA et al. (1998).
The extraction of ascorbic acid (AA) and conversion of AA to dehydroascorbic acid (DHA) in fresh pulp were performed according to CAMPOS et al. (2009). The analyzes of ascorbic acid were performed by HPLC-DAD (CAMPOS et al., 2009). The DHA content in the pulp was calculated using the formula $: D H A$ content $=$ content of $A A$ after conversion - content of $A A$ before.

The vitamin $\mathrm{E}$ isomers $(\alpha-, \beta-, \gamma-$ and $\delta$-tocopherol and tocotrienol) in fresh pulp were extracted according to PINHEIRO-SANT'ANA et al. (2011). For analysis a HPLC system (Shimadzu, model SCL 10AD VP) was employed, consisting of a high-pressure pump with valve for lowpressure quaternary gradient (model LC-10AD VP), autosampler with loop of $50 \mu \mathrm{L}$ (model SIL-10AF), helium degassing mobile phase system (Shimadzu, model DGU-2 A) and fluorescence detector (model RF-10A XL). For analysis, the chromatographic conditions proposed by PINHEIRO-SANT'ANA et al. (2011) were used.

Qualitative identification of the compounds was performed comparing the retention times obtained for standards and samples analyzed under the same conditions. Moreover, the vitamin E isomers were identified by co-chromatography and carotenoid isomers, and AA by comparing the absorption spectra of the standard and of the peaks of interest in the samples, using the DAD.

The isomers identified in the biribiri pulp were quantified by external standard curves. Curves were constructed by injection, in duplicate, of six increasing concentrations of standard solutions in the range between 0.0589 and $5.8800 \mathrm{mg}$ for ascorbic acid (1.02 and 104.21 ng), for $\alpha$-tocopherol (2.01 and $204.12 \mathrm{ng}$ ), for $\alpha$-tocotrienol (2.22 and 107.60 $\mathrm{ng}$ ), for $\mathrm{y}$-tocopherol and (3.21 and $157.60 \mathrm{ng}$ ) for $\mathrm{y}$-tocotrienol. The real concentration in the fruits was calculated based on the performed dilutions.

The quantification of the compounds was performed from calibration curves and regression equations with $\mathrm{R}^{2}$ greater than 0.997 . The final concentration was obtained by corrected calculations for the dilutions and concentrations performed during the extraction and analysis procedures.

\section{Determination of minerals and trace elements}

The lyophilized samples were digested in tubes containing nitric acid according to (EKHOLM, 2007). The content of minerals and trace elements was analyzed by inductively coupled plasma atomic emission spectrometry (Optima 3300 DV, Perkin Elmer, USA). The components in

Ciência Rural, v.52, n.3, 2022. 
the samples were quantified using external standards that consist of standard multi-element solutions. The analytical curves, with $\mathrm{R}^{2}$ greater than 0.982 , were obtained from the analysis of six solutions with different concentrations.

\section{Experimental design and data analysis}

For chemical analysis, an internally randomized design with three replications was used. Each repetition consisted of 20 fruits from 10 different trees, totaling approximately $250 \mathrm{~g}$. Descriptive statistics (means, standard deviations, and parameter range) were performed for each parameter. To evaluate the linearity range of the analytical patterns of carotenoids, vitamins and minerals, the data obtained after the analysis (peak areas or absorbances) and the concentrations of each compound were used for linear regression analysis and for the calculation of the determination coefficient $\left(\mathrm{R}^{2}\right)$. Statistical analyzes were performed using the SPSS software version 16.0 (SPSS, Inc.).

\section{RESULTS AND DISCUSSION}

\section{Physical characterization}

The biribiri fruits analyzed in this study can be described as elongated berries, thin skin, with a waxy texture-and a bright yellow-green color. Inside, the fruit showed white, slightly translucent, gelatinous, and juicy pulp, and few brown colored, elliptical and flat seeds (Figure 1).

The fruits presented, on average, $8.2 \pm 1.3$ $\mathrm{cm}$ in length and $2.5 \pm 0.3 \mathrm{~cm}$ in diameter, with a high amplitude of these parameters (from 5.2 to $11.2 \mathrm{~cm}$ and from 2.2 to $3.1 \mathrm{~cm}$, respectively). The average fruit mass, which includes peel, pulp and seeds, was $28.9 \pm 2.4 \mathrm{~g}$ (from $22.1 \mathrm{~g}$ to $32.5 \mathrm{~g}$ ). Despite being relatively small, biribiri is a totally edible fruit, that is, it has a high yield, which facilitates its full use in daily cooking (STORCK et al., 2013). In general, the fruits from the Middle Doce River had dimensions and mass, at least, $25 \%$ greater than ripe fruits harvested in India (BHASKAR \& SHANTARAM, 2013) (4.9 cm x $2.0 \mathrm{~cm}$ and $10.4 \mathrm{~g})$.

The high variability in the physical aspects of biribiri fruits analyzed in this study, as well as the differences in relation to that reported in the scientific literature, were expected. In general, biribiri fruits grow naturally in the environment, that is, without anthropic interference and standardization regarding cultivation techniques (SANTOS et al., 2014). Thus, without human influence, the edaphoclimatic conditions of the cultivation sites may exert a more evident effect during fruit development, thus resulting in greater variability in the characteristics (LIMA et al., 2001). As a result of these interferences, it is noteworthy that the analyzed fruits were grown spontaneously in a yard managed by means of agroecological techniques, based on sustainable management practices, respect for the diversity of crops, use of alternative syrups for controlling insects, composting, biofertilizers, use of ash and manure, and with absence of chemical inputs.

\section{Chemical characteristics}

Biribiri pulp showed low soluble solids and $\mathrm{pH}$, and high titratable acidity (Table 1). The $\mathrm{pH}$ of the pulp was lower than that of fruits recognized as acidic by the population, such as lemon, acerola,

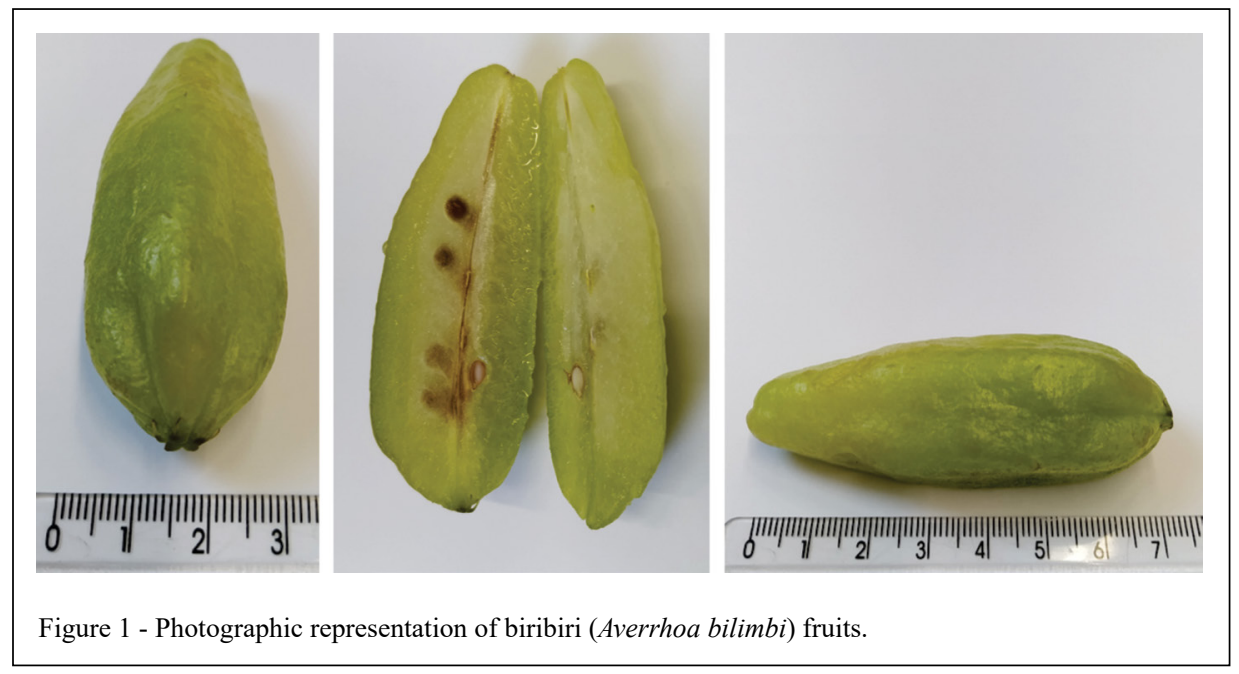

Ciência Rural, v.52, n.3, 2022. 
Table 1 - Chemical characteristics and total energy value in biribiri (Averrhoa bilimbi) cultivated in Governador Valadares (Minas Gerais, Brazil).

\begin{tabular}{|c|c|}
\hline Parameters & Content ${ }^{\mathrm{a}, \mathrm{b}}$ \\
\hline Soluble solids ( $\left.{ }^{\circ} \mathrm{Brix}\right)$ & $3.2 \pm 0.9$ \\
\hline Titratable acidity (g citric acid/100g) & $1.3 \pm 0.2$ \\
\hline $\mathrm{pH}$ & $1.5 \pm 0.1$ \\
\hline Moisture (g $\left.100 \mathrm{~g}^{-1}\right)$ & $93.2 \pm 0.6$ \\
\hline Protein $\left(\mathrm{g} 100 \mathrm{~g}^{-1}\right)$ & $0.71 \pm 0.1$ \\
\hline Lipids (g $\left.100 \mathrm{~g}^{-1}\right)$ & $0.32 \pm 0.1$ \\
\hline Ash $\left(g_{\left.100 g^{-1}\right)}\right.$ & $0.24 \pm 0.1$ \\
\hline Total dietary fiber $\left(\mathrm{g} 100 \mathrm{~g}^{-1}\right)$ & $0.62 \pm 0.2$ \\
\hline Carbohydrates available $\left(\mathrm{g} 100 \mathrm{~g}^{-1}\right)$ & $4.91 \pm 0.5$ \\
\hline Total energy value ( $\mathrm{kcal} 100 \mathrm{~g}^{-1}$ ) & $25.36 \pm 2.4$ \\
\hline
\end{tabular}

${ }^{a}$ Values are expressed in fresh matter. ${ }^{b}$ Mean of three repetitions \pm standard deviation.

and passion fruit. The acidity of fruits collected in the Middle Doce River varied within the range observed by other authors (Semi-mature: 1.15; ripe: 1.66) (ARAÚJO et al., 2009). The acidic taste of the pulp is a striking feature of biribiri, which strongly influences its use in human food. Because of this, the fresh consumption of the fruit is reduced, being the fruit used in place of lemon in the seasoning of meat and fish or in the production of preserves, jams, sweets, juices, jams, liqueurs and vinegars (ARAÚJO et al., 2009).

The biribiri fruits analyzed in this study presented high moisture and within the range observed in other studies (93.61\%, and 95.7\%) (SOUZA et al., 2011). High moisture contributes to a shorter biribiri shelf life when stored at room temperature, by increasing its perishability and susceptibility to deteriorating microorganisms (HUBERT et al., 2019). Thus, biribiri needs to be consumed soon after harvest, or subjected to refrigeration or freezing for storage.

The pulp analyzed presented low concentration of lipids, proteins, and available carbohydrates and, due to this, low total energy value. The fruit also presented low total dietary fiber content and ash. Despite the similar caloric value, the fruits of the Middle Doce River region presented different macronutrient composition, with more carbohydrates and fewer proteins and lipids than that observed in fruits of the Brazilian municipality of Cacoal (Rondônia) (VIRGOLIN et al., 2017).

\section{Carotenoids and vitamins}

Among the carotenoids studied, $\beta$-carotene $(0.16 \mathrm{mg})$ and $\beta$-cryptoxanthin $(0.16 \mathrm{mg})$ were identified in biribiri pulp, in equal proportion (Figure 2; Table 2). The $\beta$-carotene content was similar to that observed in Cacoal fruits $(0.12 \mathrm{mg})$ (Rondônia, Brazil) (VIRGOLIN et al., 2017); however, approximately 5 times higher than the result obtained in fruits collected in Fraser Town $(0.031 \mathrm{mg}$ ) (Bangalore, India) (PERIS et al., 2013). The two studies mentioned above did not perform $\beta$-cryptoxanthin analysis on biribiri fruits.

Information on the presence and content of $\alpha$-cryptoxanthin, $\beta$-cryptoxanthin and lycopene is not available in the literature. It is noteworthy that the total content of carotenoids in biribiri was low when compared to carotenoid source fruits, such as
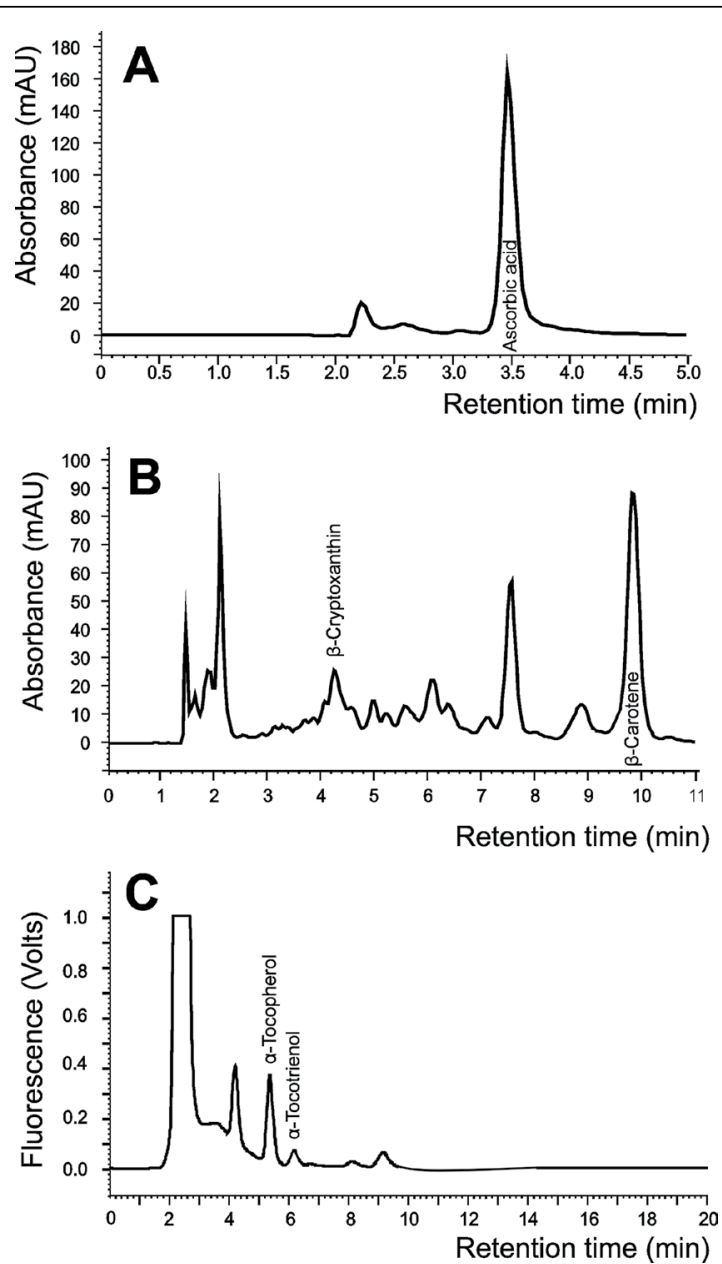

Figure 2 - Chromatograms of analyses of vitamin C (A), carotenoid (B) and vitamin E (C) in biribiri (Averrhoa bilimbi).

Ciência Rural, v.52, n.3, 2022. 
Table 2 - Carotenoid content, vitamins and minerals in biribiri (Averrhoa bilimbi) grown in Governador Valadares (Minas Gerais, Brazil).

\begin{tabular}{|c|c|c|c|}
\hline Parameters & Content $^{\mathrm{a}, \mathrm{b}}$ & Minerals & Content $^{\mathrm{a}, \mathrm{b}}\left(\mathrm{mg} 100 \mathrm{~g}^{-1}\right)$ \\
\hline Total carotenoids (mg $100 \mathrm{~g}^{-1}$ ) & $0.32 \pm 0.02$ & $\mathrm{Ca}$ & $6.32 \pm 0.14$ \\
\hline$\beta$-carotene & $0.16 \pm 0.02$ & $\mathrm{Fe}$ & $3.21 \pm 0.27$ \\
\hline$\beta$-cryptoxanthin & $0.16 \pm 0.02$ & $\mathrm{Mg}$ & $5.25 \pm 0.92$ \\
\hline Total vitamin $\mathrm{C}\left(\mathrm{mg} 100 \mathrm{~g}^{-1}\right)$ & $47.59 \pm 3.88$ & $\mathrm{Mn}$ & $0.25 \pm 0.00$ \\
\hline Ascorbic Acid & $47.59 \pm 3.88$ & $\mathrm{Se}$ & $0.00 \pm 0.00$ \\
\hline Dehydrocorasbic Acid & nd & $\mathrm{Cu}$ & $0.041 \pm 0.01$ \\
\hline Total Vitamin E ( $\left.\mu \mathrm{g} 100 \mathrm{~g}^{-1}\right)$ & $17.62 \pm 0.51$ & Mo & $0.005 \pm 0.01$ \\
\hline$\alpha$-tocopherol & $12.29 \pm 0.51$ & $\mathrm{Zn}$ & $0.04 \pm 0.02$ \\
\hline$\alpha$-tocotrienol & $5.33 \pm 0.00$ & $\mathrm{Na}$ & $5.3 \pm 0.12$ \\
\hline$\beta$-tocopherol & nd & $\mathrm{K}$ & $7.42 \pm 0.69$ \\
\hline$\beta$-tocotrienol & nd & $\mathrm{Cr}$ & $0.003 \pm 0.01$ \\
\hline$\gamma$-tocopherol & nd & $\mathrm{Al}$ & Trace \\
\hline$\gamma$-tocotrienol & nd & $\mathrm{Cd}$ & $0.00 \pm 0.00$ \\
\hline$\delta$-tocopherol & nd & $\mathrm{Ni}$ & Trace \\
\hline$\delta$-tocotrienol & nd & & \\
\hline
\end{tabular}

${ }^{\mathrm{a}}$ Values are expressed in fresh matter. ${ }^{\mathrm{b}}$ Mean of three repetitions \pm standard deviation. nd: not detected.

including papaya (7.48 $\left.\mathrm{mg} 100 \mathrm{~g}^{-1}\right)$ and guava (7.34 $\mathrm{mg} 100 \mathrm{~g}^{-1}$ ) (OLIVEIRA et al., 2010). However, this content was higher than in fruits of the same family, such as carambola $\left(0.22 \mathrm{mg} 100 \mathrm{~g}^{-1}\right)$ (LIRA JÚNIOR et al., 2014).

Carotenoids have a range of functions in human health (EGGERSDORFER \& WYSS, 2018). Among these functions, it is highlighted that the carotenoids identified in the present study performed the basic function of provitamin A, being essential for the proper functioning of vision (AMENGUAL, 2019). In addition, recent investigations have demonstrated that $\beta$-cryptoxanthin has the bioactivity to promote health, such as antioxidant, antiinflammatory, anti-obesity and anti-cancer activities, and enhance bone health (JIAO et al., 2019).

Biribiri pulp showed high vitamin $\mathrm{C}$ content present exclusively in the form of ascorbic acid (Table 2). This concentration was up to four times higher than that observed in fruits of the states of Paraíba and Rondônia (9.92 mg $100 \mathrm{~g}^{-1}$ to 41.69 $\mathrm{mg} 100 \mathrm{~g}^{-1}$ ) (ARAÚJO et al., 2009; VIRGOLIN et al., 2017). These variations can be justified by factors such as the location of the plantations, different cultural treatments, and types of soil.

Biribiri has vitamin $\mathrm{C}$ content higher than

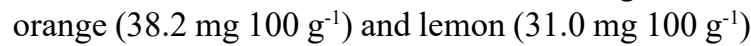
(UNICAMP, 2011), which are popularly recognized as the source of this micronutrient. Vitamin C, present in food in the form of ascorbic acid, performs basic functions in the human body, including neuronal differentiation, maturation, myelin formation and modulation of the cholinergic, catecholinergic, and glutaminergic systems (JIAO et al., 2019). However, this vitamin also stands out due to its non-nutrient function acting as an important circulating antioxidant with anti-inflammatory and immune support effects (SPOELSTRA-DE MAN et al., 2018).

Only two of the eight vitamin E components were identified in biribiri pulp ( $\alpha$-tocopherol, $69.75 \%$; $\alpha$-tocotrienol, $30.25 \%$ ). Studies on the complete profile of vitamin $\mathrm{E}$ homologues in biribiri are unavailable. As in this study, $\alpha$-tocopherol was the only vitamin E component found in Malaysian biribiri fruits (ZAINUDIN et al., 2014).

Although, a reduced vitamin E content has been identified, the vitamin $\mathrm{E}$ profile in the biribiri pulp should be highlighted. The $\alpha$-tocopherol, main component, is recognized as a single compound with a vitamin function; therefore, essential in the human body (COMITATO et al., 2017). The $\alpha$-tocotrienol, secondary component, has countless benefits to the human body due to their antioxidant action. It has often been reported that this compound plays a protective activity in normal neuronal cells and, in general, in the central nervous system (COMITATO 
et al., 2017). For example, preclinical studies showed that tocotrienol could reduce oxidative stress by acting as a free-radical scavenger and promoter of mitochondrial function and cellular repair. Human epidemiological studies showed a significant inverse relationship between tocotrienol levels and the occurrence of Alzheimer's disease (CHIN \& TAY, 2018).

Information on the concentration of vitamin $\mathrm{E}$ of biribiri pulp is scarce, which reinforces the importance of evaluating its presence in the fruit. Vitamin E content in biribiri pulp in Minas Gerais was low; however, two to six times higher than that observed in biribiri and carambola grown in Malaysia (YAN et al., 2013). Due to the reduced content, the consumption of $100 \mathrm{~g}$ of biribiri can supply only $0.22 \%$ of vitamin E recommended for adults (19-30 years) $\left(1500 \mu \mathrm{g} \mathrm{day}^{-1}\right)$.

\section{Minerals}

Biribiri pulp showed expressive zinc and copper contents and is an excellent source of iron, manganese, molybdenum, and chromium (Table 2). Magnesium, calcium and potassium contents were two to six times lower than that observed in fruits harvested in Kolhapur, India (11.16 mg $100 \mathrm{~g}^{-1} ; 20.14$

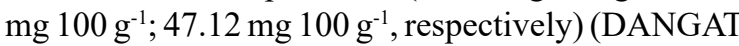
et al., 2014). The fruits analyzed in this study also presented lower copper and sodium contents than Asian fruits (BHASKAR \& SHANTARAM, 2013).

The biribiri of the Middle Doce River presented contents of some minerals higher than that observed in fruits of Asia, which had lower content of copper $\left(2.17^{-4} \mathrm{mg} 100 \mathrm{~g}^{-1}\right)$, iron $(0.103 \mathrm{mg} 100$ $\left.\mathrm{g}^{-1}\right)$, manganese $\left(1.54^{-4} \mathrm{mg} 100 \mathrm{~g}^{-1}\right)$, molybdenum $\left(1.24^{-4} \mathrm{mg} 100 \mathrm{~g}^{-1}\right)$ and zinc $\left(0.079 \mathrm{mg} 100 \mathrm{~g}^{-1}\right)$ (DANGAT et al., 2014). In addition, the fruits analyzed presented more sodium $\left(2.1 \mathrm{mg} 100 \mathrm{~g}^{-1}\right)$ and less potassium $\left(103.03 \mathrm{mg} 100 \mathrm{~g}^{-1}\right)$ than biribiri from Asia, which, like the fruits of the Middle Doce River, did not contain selenium (BHASKAR \& SHANTARAM, 2013).

The wide variation between the mineral content in the fruits evaluated in this and other scientific studies can be justified by the influence of genetic and edaphoclimatic factors of the cultivation sites. In addition to these factors, we highlighted the agroecological management of the family production unit that donated the fruits evaluated in the present study, which were free of pesticides and industrialized chemical fertilizers, and were grown spontaneously and developed without standardization regarding cultivation techniques (LIMA et al., 2001; SANTOS et al., 2014).

Biribiri pulp of the Middle Doce River was free from cadmium but presented traces of aluminum and nickel. These results contribute to the field of food nutrition, considering the health risk imposed on the population when subjected to the consumption of fruits with heavy metal content (SHAHEEN et al., 2016). In addition, it may reflect a positive influence of the practices adopted in the place where the fruits were collected.

The presence of nickel in biribiri fruits was also observed in fruits collected in a district of India $\left(1.6^{-3} \mathrm{mg} 100 \mathrm{~g}^{-1}\right)$ (SOUMYA \& NAIR, 2016). The difference observed between nickel levels in studies, although low, can result from soil and water contamination by this heavy metal, which is absorbed by plants through the root system (SOUMYA \& NAIR, 2016).

\section{CONCLUSION}

Biribiri was characterized, therefore, as a species with potential for the promotion of health and food sovereignty of family agriculture for presenting expressive content of vitamin c, iron, manganese, molybdenum, chromium, zinc, and copper and low content of heavy metals. It is still necessary to conduct studies on the antinutritional factors present in biribiri, such as oxalic acid, which is present in fruits belonging to the oxalidaceae family.

\section{ACKNOWLEDGMENTS}

To centro agroecológico tamanduá and mr. Geraldo magela ferreira e silva, a family farmer who donated the biribiri fruits analyzed in this study.

This study was financed by Fundação de Amparo à Pesquisa do Estado de Minas Gerais (FAPEMIG) - APQ-0072018); and by the Coordenação de Aperfeiçoamento de Pessoal de Nível Superior - Brasil (CAPES) - Finance Code 001".

\section{DECLARATION OF CONFLICT OF INTEREST}

The authors declare no conflict of interest. The founding sponsors had no role in the design of the study; in the collection, analyses, or interpretation of data; in the writing of the manuscript, and in the decision to publish the results.

\section{AUTHORS' CONTRIBUTIONS}

All authors contributed equally for the conception and writing of the manuscript. All authors critically revised the manuscript and approved of the final version.

REFERENCES

Ciência Rural, v.52, n.3, 2022. 
ALHASSAN, A. M.; AHMED, Q. U. Averrhoa bilimbi linn.: a review of its ethnomedicinal uses, phytochemistry, and pharmacology. Journal of pharmacy \& bioallied sciences, v.8, n.4, p.265, 2016. Available from: <https://pubmed.ncbi.nlm.nih. gov/28216948/>. Accessed: Mar. 16, 2020. doi: 10.4103/09757406.199342

AMENGUAL, J. Bioactive properties of carotenoids in human health. Nutrients. v.11, n.10, p.2388, 2019. Available from: $<$ https://www.ncbi.nlm.nih.gov/pmc/articles/PMC6835724/>. Accessed: Jun. 10, 2020. doi: 10.3390/nu111023882019.

AOAC. Official methods of analysis of association of official analytical chemists international. 20 ed. Association of Official Analytical Chemists International, 2016.

ARAÚJO, E. R. et al. Physicochemical characterization of biri-biri fruits (Averrhoa bilimbi L.). Biotemas, 22, n.4, p.225230, 2009. Available from: <https://doi.org/10.5007/21757925.2009v22n4p225>. Accessed: Mar. 16, 2020. doi: 10.5007/2175-7925.2009v22n4p225.

ARIHARAN, V. et al. An exotic fruit which forms the new natural source for vitamin-C. Rasayan J Chem, v.5, p.356359, 2012. Available from: <https://www.researchgate.net/ publication/236632165_An_exotic_fruit_which_forms_the_new_ natural_source_for_vitamin-C $>$. Accessed: Mar. 16, 2020.

BHASKAR, B.; SHANTARAM, M. Morphological and biochemical characteristics of Averrhoa fruits. International Journal of Pharmaceutical, Chemical and Biological Sciences, v.3, n.3, p.924-928, 2013. Available from: <https://www. researchgate.net/publication/256965958 Morphological and biochemical_characteristics_of_Averrhoa_fruits $>$. Accessed: Apr. 04, 2020.

CAMPOS, F. M. et al. Optimization of methodology to analyze ascorbic and dehydroascorbic acid in vegetables. Quimica Nova, v.32, n.1, p.87-91, 2009. Available from: <https://doi.org/10.1590/ S0100-40422009000100017>. Accessed: Mar. 16, 2020. doi: 10.1590/S0100-40422009000100017.

CHIN, K. Y.; TAY, S. S. A Review on the Relationship between Tocotrienol and Alzheimer Disease. Nutrients, v.10, n.7, p.881, 2018. Available from: <https://www.ncbi.nlm.nih.gov/pmc/ articles/PMC6073491/>. Accessed: Jun. 10, 2020. doi: 10.3390/ nu10070881.

COMITATO, R. et al. Tocotrienols: a family of molecules with specific biological activities. Antioxidants, v.6, n.4, p.93, 2017. Available from: <https://pubmed.ncbi.nlm.nih.gov/29156559/>. Accessed: Jun. 10, 2020. doi: 10.3390/antiox6040093.

DANGAT, B. T. et al. Mineral analysis of Averrhoa bilimbi L. A potential fruit. Asian J Pharm Clin Res, v.7, n.3, 2014. Available from: <https://innovareacademics.in/journals/index.php/ajpcr/ article/view/1242>. Accessed: apr. 04, 2020.

EGGERSDORFER, M.; WYSS, A. Carotenoids in human nutrition and health. Archives of biochemistry and biophysics, v.652, p.18-26, 2018. Available from: <https://pubmed.ncbi.nlm. nih.gov/29885291/>. Accessed: Jun. 10, 2020. doi: 10.1016/j. abb.2018.06.001.

EKHOLM P., R. H. et al. Changes in the mineral and trace element contents of cereals, fruits and vegetables in Finland. J. Food Compos. Anal., v.20, n.6, p.487-495, 2007. Available from: $<$ https://doi.org/10.1016/j.jfca.2007.02.007>. Accessed: Mar. 16, 2020. doi: 10.1016/j.jfca.2007.02.007

FLORENTINO, A. T. N. et al. Contribution of homegardens to the conservation of caatinga plants, Municipality of Caruaru, Pernambuco State, Brazil. Acta botanica brasilica, v.21, n.1, p.37-47, 2007. Available from: <https://doi.org/10.1590/S010233062007000100005>. Accessed: Mar. 16, 2020. doi: 10.1590/ S0102-33062007000100005.

HUBERT, G. et al. Influence of drying conditions on the moisture of pearl pineapple (Ananas Comosus (L.) Merril). In: Anais do Salão Internacional de Ensino, Pesquisa e Extensão. v.10, n.2, 2019. Anais eletrônicos. Available from: <https://guri.unipampa.edu.br/ uploads/evt/arq trabalhos/17047/seer_17047.pdf $>$. Accessed: Jun. $10,2020$.

ISTIQAMAH, A. et al. Umami compounds present in low molecular umami fractions of asam sunti-A fermented fruit of Averrhoa bilimbi L. Food chemistry, v.270, p.338-343, 2019. Available from: <https://pubmed.ncbi.nlm.nih.gov/30174056/>. Accessed: Mar. 16, 2020. doi: 10.1016/j.foodchem.2018.06.131.

JIAO, Y. et al. $\beta$-Cryptoxanthin: Chemistry, Occurrence, and Potential Health Benefits. Current Pharmacology Reports, v.5, n.1, p.20-34, 2019. Available from: <https://www.researchgate. net/publication/330631513_b-Cryptoxanthin_Chemistry_ Occurrence_and_Potential_Health_Benefits $>$. Accessed: Jun. 10, 2020. doi: 10.1007/s40495-019-00168-7.

LIMA, V. L. A. G. et al. Physicochemical characteristics of bilimbi (Averrhoa bilimbi L.). Revista Brasileira de Fruticultura, v.23, n.2, p.421-423, 2001. Available from: <https://doi.org/10.1590/ S0100-29452001000200045>. Accessed: Mar. 16, 2020. doi: 10.1590/S0100-29452001000200045.

LIRA JÚNIOR, J. S. D. et al. Antioxidant compounds in fruits of Averrhoa carambola accessions under different environments in the state of Pernambuco, Brazil. Revista Brasileira de Fruticultura, v.36, p.813-819, 2014. Available from: $<$ https://doi. org/10.1590/0100-2945-306/13>. Accessed: Jun. 10, 2020. doi: $10.1590 / 0100-2945-306 / 13$.

LUTZ, I. A. Métodos físico-químicos para análise de alimentos. São Paulo: Instituto Adolfo Lutz. 2008. 1020 p.

MAHAN L. K. et al. Krause, alimentos, nutrição \& dietoterapia. 11 ed. São Paulo: Roca, 2005. 1157 p.

MIEAN, K. H.; MOHAMED, S. Flavonoid (myricetin, quercetin, kaempferol, luteolin, and apigenin) content of edible tropical plants. Journal of agricultural and food chemistry, v.49, n.6, p.3106-3112, 2001. Available from: <https://pubmed.ncbi.nlm. nih.gov/11410016/>. Accessed: Apr. 04, 2020. doi: 10.1021/ jf000892m.

MUHAMAD, N. et al. Thermal degradation kinetics of nicotinic acid, pantothenic acid and catechin derived from Averrhoa bilimbi fruits. RSC Advances, v.5, n.90, p.74132-74137, 2015. Available from: <https://pubs.rsc.org/en/content/articlelanding/2015/RA/ c5ra11950b\#!divAbstract>. Accessed: Mar. 16, 2020. doi: 10.1039/ C5RA11950B.

OLIVEIRA, D. D. S. et al. Carotenoids and vitamin C during

Ciência Rural, v.52, n.3, 2022. 
Handling and Distribution of Guava (Psidium guajava L.), Mango (Mangifera indica L.), and Papaya (Carica papaya L.) at Commercial Restaurants. Journal of Agricultural and Food Chemistry, v.58, n.10, p.6166-6172, 2010. Available from: $<$ https://pubmed.ncbi.nlm.nih.gov/20441159/>. Accessed: Jun. 10, 2020. doi: 10.1021/jf903734x.

PERIS, C. et al. Nutritional and biochemical evaluation of Averrhoa bilimbi L. Archives of Pharmacy and Biological Sciences, v.1, n.2, p.58-62, 2013. Available from: <https://www.researchgate. net/publication/262917280_Nutritional_and_biochemical evaluation_of_Averrhoa_bilimbi_L>. Accessed: Jü. 10, 2020.

PINHEIRO-SANT'ANA H.M. et al. Method for simultaneous analysis of eight vitamin $\mathrm{E}$ isomers in various foods by high performance liquid chromatography and fluorescence detection. $\mathbf{J}$. Chromatogr A, v.1218, n.47, p.8496-8502, 2011. Available from: $<$ https://doi.org/10.1016/j.chroma.2011.09.067>. Accessed: Mar. 16, 2020. doi: 10.1016/j.chroma.2011.09.067.

PINHEIRO-SANT'ANA, H. M. et al. Carotenoid retention and vitamin A value in carrot (Daucus carota L.) prepared by food service. Food Chemistry, v.61, n.1-2, p.145-151, 1998. Available from: <https://doi.org/10.1016/S0308 8146(97)00084-8>. Accessed: Mar. 16, 2020. doi: 10.1016/ S0308-8146(97)00084-8.

RAMSAY, A.; MUELLER-HARVEY, I. Procyanidins from Averrhoa bilimbi fruits and leaves. Journal of Food Composition and Analysis, v.47, p.16-20, 2016. Available from: <https://doi. org/10.1016/j.jfca.2015.12.004>. Accessed: Apr. 04, 2020. doi: 10.1016/j.jfca.2015.12.004

RODRIGUEZ-AMAYA, D. et al. Carotenoid pigment changes in ripening Momordica charantia fruits. Ann Bot, v.40, n.3, p.615-624, 1976. Available from: <https://doi.org/10.1093/ oxfordjournals.aob.a085171>. Accessed: Mar. 16, 2020. doi: 10.1093/oxfordjournals.aob.a085171.

SANTOS, H. H. D. et al. Fruits, seeds and seedlings morphology of Averrhoa bilimbi L. derived from two stages of maturation. Ciência Rural, v.44, n.11, p.1995-2002, 2014. Available from: $<$ https://doi.org/10.1590/0103-8478cr20130992>. Accessed: Jun. 10, 2020. doi: 10.1590/0103-8478cr20130992.

SHAHEEN, N. et al. Presence of heavy metals in fruits and vegetables: health risk implications in Bangladesh. Chemosphere, v.152, p.431-438, 2016. Available from: <https://doi.org/10.1016/j. chemosphere.2016.02.060>. Accessed: Jun. 14, 2020. doi: 10.1016/j.chemosphere.2016.02.060.

SOUMYA, S.; NAIR, B. R. Assessment of heavy metals in Averrhoa bilimbi and A. carambola fruit samples at two developmental stages. Environmental monitoring and assessment, v.188, n.5, p.291, 2016. Available from: <https://pubmed.ncbi.nlm.nih. gov/27080855/>. Accessed: Mar. 16, 2020. doi: 10.1007/s10661016-5298-z.

SOUZA, P. D. et al.. Physicochemical characterization of bilmbí fruits (Averrhoa bilimbi L.) Cultivated in rn state. Revista Verde, v.6, p.270273, 2011. Available from: <https://www.gvaa.com.br/revista/index php/RVADS/article/view/643>. Accessed: Mar. 16, 2020.

SPOELSTRA-DE MAN, A. M. et al. Vitamin C: should we supplement?. Current opinion in critical care, v.24, n.4, p.248, 2018. Available from: <https://journals.lww.com/cocriticalcare/Fulltext/2018/08000/Vitamin C should we supplement .6.aspx>. Accessed: Jun. 10, 2020. doi: 10.1097/ MCC.0000000000000510.

STORCK, C. R. et al. Leaves, stalk, pell and seeds of vegetables: nutritional composition, utilization and sensory analysis in food preparations. Ciência Rural, v.43, n.3, p.537-543, 2013. Available from: $\quad<$ https://doi.org/10.1590/S0103-84782013000300027>. Accessed: Jun. 10, 2020. doi: 10.1590/S0103-84782013000300027.

UNICAMP. Tabela brasileira de composição de alimentos TACO. 4 ed. Campinas: NEPA-UNICAMP. 2011. 161 p. Available from: $<$ https://www.cfn.org.br/wp-content/uploads/2017/03/taco_4_ edicao_ampliada_e_revisada.pdf $>$. Accessed: Jun. 10, 2020.

VIRGOLIN, L. B. et al. Composition, content of bioactive compounds, and antioxidant activity of fruit pulps from the Brazilian Amazon biome Pesquisa Agropecuária Brasileira, v.52, n.10, p.933-941, 2017. Available from: <https://doi.org/10.1590/ s0100-204x2017001000013>. Accessed: Jun. 10, 2020. doi: 10.1590/s0100-204x2017001000013.

YAN, S. W. et al. A comparative assessment of nutritional composition, total phenolic, total flavonoid, antioxidant capacity, and antioxidant vitamins of two types of Malaysian underutilized fruits (Averrhoa bilimbi and Averrhoa carambola). International journal of food properties, v.16, n.6, p.1231-1244, 2013. Available from: <https://doi.org/10.1080/10942912.2011.582975 >. Accessed: Apr. 04, 2020. doi: 10.1080/10942912.2011.582975.

ZAINUDIN, M. A. M. et al. Variation of bioactive compounds and antioxidant activity of carambola (Averrhoa carambola L.) fruit at different ripening stages. Scientia Horticulturae, v.172, p.325-331, 2014. Available from: <https://doi.org/10.1016/j. scienta.2014.04.007>. Accessed: Apr. 04, 2020. doi: 10.1016/j. scienta.2014.04.007. 